\title{
Assessment of Commercially Safflower Oils (Carthami Oleum Raffinatum) in Terms of European Pharmacopoeia Criteria and Their Weight Control Potentials
}

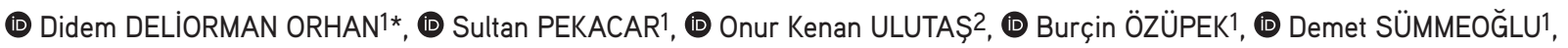 \\ (1) Aysel BERKKAN3
}

${ }^{1}$ Gazi University, Faculty of Pharmacy, Department of Pharmacognosy, Ankara, Türkiye

${ }^{2}$ Gazi University, Faculty of Pharmacy, Department of Toxicology, Ankara, Türkiye

3 Gazi University, Faculty of Pharmacy, Department of Analytical Chemistry, Ankara, Türkiye

\begin{abstract}
Objectives: Safflower oils, which are sold commercially, are in demand with food, cosmetics, and health-promoting claims. In this study, safflower oil samples belonging to 11 different brands were evaluated in terms of European Pharmacopoeia Criteria 7.0. Additionally, in vitro weight control potential of all samples was investigated.

Materials and Methods: Samples to be analyzed were purchased from pharmacies, herbal, online, and cosmetics stores. Acid and peroxide values of 11 safflower samples and analysis of their fatty acids by gas chromatography-mass spectrometry (GC-MS) were carried out according to the "Carthami oleum raffinatum" monograph registered in the European Pharmacopeia 7.0. To test the effects of all samples on weight control, their inhibitory effects on carbohydrate-digesting enzymes ( $\alpha$-glucosidase and $\alpha$-amylase) were evaluated using spectrophotometric methods.

Results: Out of 11 oil samples, only two of them had acid and peroxide values below the reference value. According to GC analysis, safflower oil samples are rich in monounsaturated fatty acids (oleic acid) and polyunsaturated fatty acids (linoleic acid) (67.10-99.53\%) of total fatty acids in its content are oleic, linoleic, palmitic, and stearic acids. Saturated fatty acids were 0.58 to $12.18 \%$ of the total fatty acid methyl esters in oils. When evaluated in terms of the inhibition of $\alpha$-amylase and $\alpha$-glucosidase enzymes that hydrolyze carbohydrates, the results showed that safflower oil samples had no inhibitory activity on these enzymes.

Conclusion: It has been determined in this report that many safflower oil samples on the market do not meet the quality criteria recommended in European Pharmacopoeia 7.0. It was observed that safflower oil did not show any inhibitory effect on these two enzymes, which is considered a rational approach for weight control.
\end{abstract}

Key words: Fatty acids, gas chromatography-mass spectrometry, quality control, safflower oil

\section{INTRODUCTION}

Due to oil, protein, carbohydrate, mineral, and vitamins they contain, some plant seeds have a critical place in human and animal nutrition and biodiesel production. Most of the oils needed in human nutrition are obtained from vegetable oils. $92 \%$ of the world's oil production is obtained from vegetable sources and $8 \%$ from animal sources. Seeds are an important source of various vegetable oils. Fatty acid content and biological activity of seeds are the factors that determine the use of a vegetable oil in nutrition, pharmaceutical or industrial areas.,2 Vegetable oil production in the world is mainly met with palm oil, soybean, rapeseed, olive, safflower, corn, sunflower, peanut, sesame, castor oil, poppy, flax, hemp, and jojoba. Most of the vegetable oil production in Türkiye is based mainly on sunflower; sunflowers constitute $69 \%$ of vegetable oil 
production, $32 \%$ of total oil consumption. Therefore, safflower, whose production is low, may be a hope of closing vegetable oil gap in the market. $80 \%$ of world safflower production is carried out by Kazakhstan (24.6\%), Russia (19.2\%), Mexico (16.1\%), India (11.9\%), and Türkiye (8.2\%).'

Carthamus tinctorious L. is a bushy, herbaceous plant from Asteraceae family and grown in arid or semi-arid regions or where moderately salty water is used. Safflower oil (Carthami oleum raffinatum) is a fixed oil obtained by squeezing or extracting the seeds of $C$. tinctorius and then refining. ${ }^{3-5}$

Except using these oils for dietary purposes, many vegetable oils are sold with health-promoting claims or statements that they are beneficial against diseases, while safflower oils are one of them, as they are sold in "natural", "organic products", "local products" shops, cosmetics store chains, and pharmacies. Safflower oil, which is marketed for health benefits and cosmetics, must meet European Pharmacopeia criteria. Currently, these safflower oils are marketed as fixed oils with the producer's own marketing and quality criteria, while a pharmacopeia's core mission is to protect public health by creating and making available public standards to help ensure the quality of products while the user or procurer can make an independent judgment regarding quality, thus safeguarding the health of the public.

In European Pharmacopoeia 7.0, "safflower oil, refined; Carthami oleum raffinatum" is registered under the name "refined safflower oil", which is defined as oil obtained from the seeds of $C$. tinctorius (type I) or hybrid $C$. tinctorius seeds (type II) from extraction and/or extraction followed by refining. ${ }^{6}$ Type II oil is rich in oleic acid and contains antioxidant. ${ }^{7}$ Fatty acid content is one of the main factors that determine the use of a vegetable oil in nutrition, pharmaceutical or industrial areas. ${ }^{2}$

Safflower seeds contain high levels of polyunsaturated fatty acids and are used for dietetic, medical, and industrial purposes. ${ }^{8.9} 96-99 \%$ of total fatty acids in its content are oleic, linoleic, palmitic, and stearic acids, $9.7-10.8 \%$ of saturated fatty acids. ${ }^{2}$ Fatty acid composition in safflower seeds usually consists of 71 to $75 \%$ linoleic acid (C 18:2), 16 to $20 \%$ oleic acid (C18:1), 6 to $8 \%$ palmitic acid (C16:0), and 2 to $3 \%$ stearic acid (C18:0)..$^{2,10-12}$

There is much news about the use of safflower oil in weight control in the media and on the internet. Pharmacists also state that especially women often demand safflower oil for this purpose. Literature surveys have shown us that there is no scientific study on the effect of this oil on weight control. Therefore, in this study, we tested the effects of safflower oil on enzymes that digest carbohydrates, which is a rational approach to weight control. On the other hand, quality control evaluations of 11 safflower oil samples obtained from pharmacies, akhtars, and cosmetics shops were made in terms of the criteria in the relevant monograph in the European Pharmacopoeia 7.0. For this purpose, acid and peroxide values of the oil samples by volumetric method and fatty acid analysis were performed using gas chromatography-mass spectrometry (GC-MS) technique.

\section{MATERIALS AND METHODS}

\section{Chemicals and instruments}

All chemicals used were of analytical reagent grade. Heptane (99\%), potassium hydroxide $(\mathrm{KOH})$, methylene chloride $\left(\mathrm{CH}_{2} \mathrm{Cl}_{2}\right)$ for $\mathrm{GC}-\mathrm{MS}$ Supra Solv ${ }^{\circledR}$, sodium chloride $(\mathrm{NaCl})$, sodium sulfate $\left(\mathrm{Na}_{2} \mathrm{SO}_{4}\right)$, Supelco 37-component fatty acid methyl ester (FAME) mix (FAME37, C4-24), chloroform $\left(\mathrm{CHCl}_{3}\right.$ ), glacial acetic acid, acetone, phosphomolybdic acid, ether, phenolphthalein, 3,5-dinitrosalicylic acid, sodium potassium tartrate were purchased from Sigma Aldrich Co. and Riedel-de Haën (Seelze, Germany). Methanol (MeOH) containing not more than $0.5 \%(\mathrm{w} / \mathrm{w})$ water, starch, potassium iodide $(\mathrm{KI})$, sodium thiosulfate, and peroxide-free ether were purchased from Merck, Germany. Oksan Co., Ltd. (Ankara, Türkiye) provided helium, hydrogen, and dried air gas for GC with $99.99 \%$ purity. Deionized water was obtained from a Milli-Q water purification system (Millipore, Bedford, MA, USA).

GC (7890A GC System, Agilent Technologies Inc, US), a capillary column Rt-2560 (100 m, 0.25 mm ID, $0.2 \mu \mathrm{m}$ ) (Restek Corporation Bellefonte, US), vial insert, $250 \mu \mathrm{L}$, glass with polymer feet, vial, screw top, $2 \mathrm{~mL}$, amber and cap, screw, blue, polytetrafluoroethylene/red silicone septa (Agilent Technologies Inc., US), and ELISA (Versamax Tunable Microplate Reader) were used in GC analysis and enzyme activity studies, respectively.

\section{Safflower oil samples}

Eleven different brands of safflower oils were purchased from pharmacies, akhtars, online, and cosmetics stores in Ankara/ Türkiye in 2019. The samples were stored at $4^{\circ} \mathrm{C}$ until used in studies.

\section{Acid value $\left(V_{A}\right)$}

About $10 \mathrm{~g}$ of the oil $(\mathrm{m})$ was dissolved in $50 \mathrm{~mL}$ of $96 \% \mathrm{MeOH}$ and ether mixture $(1: 1, v / v)$. $0.1 \mathrm{M} \mathrm{KOH}$ was used as a titrant in the presence of phenolphthalein indicator until the pink remained stable for at least $15 \mathrm{~s}(\mathrm{n} \mathrm{mL}$ of $0.1 \mathrm{M} \mathrm{KOH})$. Acid values of samples were calculated from the equation of $V_{A}=$ $(5.610 \times n) / m$ and compared with value of maximum of 2.0 in a 5.0 g oil sample. ${ }^{13}$

\section{Peroxide value $\left(V_{P}\right)$}

About $5 \mathrm{~g}$ oil $(\mathrm{m})$ was placed in a $250 \mathrm{~mL}$ conical flask fitted with a ground-glass stopper. $30 \mathrm{~mL}$ of a mixture of $\mathrm{CHCl}_{3}$ and glacial acetic acid (2:3, v/v) was added. After the oil dissolved, $0.5 \mathrm{~mL}$ of saturated $\mathrm{KI}$ solution was added and shaken exactly $1 \mathrm{~min}$, then $30 \mathrm{~mL}$ water was added. It was titrated with $0.01 \mathrm{M}$ sodium thiosulfate until yellow color was almost discharged. $5 \mathrm{~mL}$ of starch solution was added and continued the titration, until the color was discharged $\left(n_{1} m L\right.$ of $0.01 M$ sodium thiosulfate). We carried out a blank test under the same conditions ( $n_{2} \mathrm{~mL}$ of $0.01 \mathrm{M}$ sodium thiosulfate). Volume of $0.01 \mathrm{M}$ sodium thiosulfate used in the blank titration did not exceed $0.1 \mathrm{~mL}$. Peroxide value was calculated from the equation of $V_{P}=10\left(n_{1}-n_{2}\right) / m$, and compared value of max 15.0 in 5 g oil. ${ }^{14,15}$ 
Fatty acid analysis by GC-MS

Standard mixture of 37 fatty acids methyl esters (Supelco" 37 Component FAME Mix, FAME37, C4-24) used for the GC analyses. FAME37 $(100 \mathrm{mg})$ was stored at $-20^{\circ} \mathrm{C}$ and all standard solutions were prepared in an ice bath. To prepare 400 $\mathrm{mg} / \mathrm{mL}$ FAME 37 standard solution, $250 \mu \mathrm{L}$ of $\mathrm{CH}_{2} \mathrm{Cl}_{2}$ solution was added to $100 \mathrm{mg}$ of FAME37 standard, and vortexed. 75 $\mu \mathrm{L}$ of this solution was taken into a $\mathrm{GC}$ vial and $925 \mu \mathrm{L} \mathrm{CH}_{2} \mathrm{Cl}_{2}$ was added, and then vortexed by closing the mouth. FAME37 standard solution (100 $\mu \mathrm{L} ; 30 \mathrm{mg} / \mathrm{mL})$ was placed in a 250 $\mu \mathrm{L}$ polymer-footed glass tube placed in $2 \mathrm{~mL}$ amber colored vial and sealed, then analyzed by GC-MS under the following chromatographic conditions (Table 1).

FAME were prepared by trans-esterification of the oils with $\mathrm{MeOH}$, using $\mathrm{KOH}$ as a catalyst before $\mathrm{GC}$ analysis. $2 \mathrm{~mL}$ of safflower oil sample was placed in a flat bottom, approximately $50 \mathrm{~mm}$ diameter and $30 \mathrm{~mm}$ long container and dried in the oven at $100-105^{\circ} \mathrm{C}$. It was allowed to cool in a desiccator with silica gel. $1 \mathrm{~g}$ of the oil was weighed into a $25 \mathrm{~mL}$ roundbottomed flask with a ground-glass neck fitted with a reflux condenser and a gas port into the flask. Anhydrous $\mathrm{MeOH}(10$ $\mathrm{mL}$ ) and $0.2 \mathrm{~mL}$ of $60 \mathrm{~g} / \mathrm{L} \mathrm{KOH}$ in $\mathrm{MeOH}$ were added. Then, flux condenser was attached, passed nitrogen through the mixture

\section{Table 1. GC-MS conditions}

GC conditions

\begin{tabular}{|c|c|}
\hline Component & Condition \\
\hline Device & $\begin{array}{l}\text { Agilent Technologies } 7890 \text { A GC } \\
\text { system, Agilent Technologies Inc, } \\
\text { Santa Clara, MS detector }\end{array}$ \\
\hline Column & $\begin{array}{l}\text { Restek-2560, bissyano propyl } \\
\text { polysiloxane }(100-\mathrm{m} \times 0.25 \mu \mathrm{m} \text { ID } x \\
0.20 \mu \mathrm{m})\end{array}$ \\
\hline Oven temperature & $\begin{array}{l}100^{\circ} \mathrm{C} \text { (hold } 4 \mathrm{~min} \text { ), increased to } 24^{\circ} \mathrm{C} \\
\text { by } 3^{\circ} \mathrm{C} \text { min (hold } 15 \mathrm{~min} \text { ) }\end{array}$ \\
\hline Injection temperature & $225^{\circ} \mathrm{C}$ \\
\hline Detector temperature & $250^{\circ} \mathrm{C}$ \\
\hline Carrier gas, flow rate & $\mathrm{He}, 1.0 \mathrm{~mL} / \mathrm{min}$ \\
\hline Injection volume & $2 \mu \mathrm{L}$ \\
\hline Split ratio & $100: 1$ \\
\hline \multicolumn{2}{|l|}{ MS condition } \\
\hline Component & Condition \\
\hline Device & Agilent Technologies 5977E MS \\
\hline Mode & Scan \\
\hline Solvent Delay & $11.5 \mathrm{~min}$ \\
\hline Mass range & $20-300$ \\
\hline Step size & $0.1 \mathrm{~m} / \mathrm{z}$ \\
\hline Scan speed & $3.125(u / s)$ \\
\hline Frequency & $9.0 \mathrm{scan} / \mathrm{sec}$ \\
\hline Cycle time & $110.96 \mathrm{~ms}$ \\
\hline
\end{tabular}

at a flow rate of about $50 \mathrm{~mL} / \mathrm{min}$, mixed, and heated to boiling. When the solution was clear (usually after about $10 \mathrm{~min}$ ), it was continued heating for a further $5 \mathrm{~min}$, and cooled the flask and transferred the contents were to a separating funnel. The flask was rinsed with $5 \mathrm{~mL}$ heptane, transferred the rinsing to the separating funnel, and stacked. $\mathrm{NaCl}$ solution $(10 \mathrm{~mL}$ of a $200 \mathrm{~g} / \mathrm{L}$ ) was added and stacked vigorously. It was allowed to separate two phases and transferred the upper organic layer to a vial containing anhydrous $\mathrm{Na}_{2} \mathrm{SO}_{4}$, allowed to stand, then filtered, and FAME compositions were determined by GC-MS under the chromatographic conditions (Table 1).16 Results are expressed as \% (w/w) with respect to all fatty acids detected.

\section{Enzyme inhibition methods}

\section{$\alpha$-Amylase enzyme inhibition}

The effects of safflower oil samples in $\alpha$-amylase enzyme were determined by modifying the method of Ali et al. ${ }^{17} \alpha$-Amylase enzyme (EC 3.2.1.1, type I-A, Sigma) was prepared in water at a concentration of $4 \mathrm{U} / \mathrm{mL}$. Potato starch solution $(0.5 \%)$ prepared in $20 \mathrm{mM}$ phosphate buffer was used as the substrate. Safflower oil samples were prepared in $100 \% \mathrm{MeOH}$ at concentrations of $1,0.5$, and $0.25 \mathrm{mg} / \mathrm{mL}$. The samples were treated with $\alpha$-amylase enzyme $(4 \mathrm{U} / \mathrm{mL})$ at $37^{\circ} \mathrm{C}$. They were incubated at $37^{\circ} \mathrm{C}$ and starch solution was added. Further, 50 $\mathrm{mL}$ of DNS color solution ( $96 \mathrm{mM}$ 3,5-dinitrosalicylic acid, 5.31 $M$ sodium potassium tartrate in $2 \mathrm{M} \mathrm{NaOH}$ ) was added and kept at $85^{\circ} \mathrm{C}$ for $15 \mathrm{~min}$. Later, the mixtures were diluted with water and the tubes were allowed to cool to complete the reaction. The absorbance of the mixture was measured at $540 \mathrm{~nm}$ with an ELISA (Versamax Tunable Microplate Reader) plate reader. Acarbose was used as the reference substance. The change in absorbance resulting from the amount of maltose formed was calculated using equation 1 .

The amount of maltose formation was measured using the maltose standard calibration curve (between 0.0 and $0.1 \%, \mathrm{w} / \mathrm{v}$ ) maltose concentration versus net absorbance value, $y=0.4428 \mathrm{x}$ $+0.0264, r^{2}=0.9926$. Percentages of inhibition were calculated using equation 1 .

[A (control solution) / A (oil sample)] = [A (oil sample) / A (blank)] (equation 1)

\section{A: Absorbance}

\section{$\alpha$-Glucosidase enzyme inhibition}

Inhibitory effects of the safflower oil samples on $\alpha$-glucosidase were determined using the method of Lam et al. ${ }^{18}$ The $\alpha$-glucosidase (type IV) obtained from Bacillus stearothermophilus was prepared in $0.5 \mathrm{M}$ phosphate buffer $(\mathrm{pH}$ 6.5).

Safflower oil samples were prepared by dissolving in $100 \%$ $\mathrm{MeOH}$ at concentrations of $1,0.5$, and $0.25 \mathrm{mg} / \mathrm{mL}$. The solutions were incubated with $\alpha$-glucosidase in a 96 well microplate reader at $37^{\circ} \mathrm{C}$. Subsequently, substrate solution (10 $\mu \mathrm{L}, 20 \mathrm{mM} p$-nitrophenyl- $\alpha$-D-glucopyranoside) was added and the reaction was allowed to occur at $37^{\circ} \mathrm{C}$. At the end of the 
period, color intensity was measured with an ELISA (Versamax Tunable Microplate Reader, USA) plate reader at a wavelength of $405 \mathrm{~nm}$ was used as the reference substance. Percentages of inhibition were calculated using equation 2 .

Inhibition $(\%)=[1-(\mathrm{A}$ (oil sample) $/ \mathrm{A}$ (control) $] \times 100 \quad$ (equation 2$)$

A: Absorbance

\section{Statistical analysis}

While evaluating the test results, standard deviations (SD) were calculated in MS Excel program on the Windows XP operating system. All the results were given for at least as triplicate and values were expressed as mean \pm SD.

\section{RESULTS}

Acid and peroxide values of the oil samples

Acid and peroxide values of the safflower oil samples are given in Table 2. According to European Pharmacopoeia 7.0, acid value of the safflower oils should be at most 0.5 and the peroxide value should be 10 . Except for $n_{1}$ and $n_{5}$ oils, acid value of 9 other oils is above the reference value of 0.5 . On the other hand, only $2\left(n_{1}\right.$ and $\left.n_{4}\right)$ out of 11 oil samples have the peroxide value below the reference value.

\section{Fatty acid composition of the oil samples}

The pharmacopeia mentions two types of safflower oil. The oil obtained from the seeds of $C$. tinctorius from expression and/or extraction is called type I and the oil obtained from the seeds of the hybrids of this plant is called type II fixed oil. Since it is not stated on the packages of the purchased oil samples whether the plant from which the oil is obtained is hybrid or not, the results of the fatty acid analysis were evaluated according to the results of type I oil (Table 3 ).

Quantitative analysis of fatty acids contained in the samples was carried out over the peak areas by comparing the retention times of standard fatty acids and the results are given in Table 4. According to this, safflower oil samples are rich in monounsaturated (oleic acid) and polyunsaturated (linoleic acid) fatty acids (67.10-99.53\%) of total fatty acids in its content are oleic, linoleic, palmitic, and stearic acids. Saturated fatty acids are 0.58 to $12.18 \%$ of the total FAMEs in oils. The fatty acid composition in safflower oils consisted of 47.04 to $92.59 \%$ linoleic acid (C18:2), 4.09 to $40.34 \%$ oleic acid (C18:1), 0.54 to $12.01 \%$ palmitic acid (C16:0), and 0.05 to $1.35 \%$ stearic acid (C18:0). Considering all these results and the values in the monograph, it was seen that none of the oil samples were suitable for the pharmacopeia.

\section{Table 2. Acid and peroxide values of the oil samples}

\begin{tabular}{|c|c|c|c|c|c|c|c|c|c|c|c|}
\hline Samples & $\mathrm{n}_{1}$ & $\mathrm{n}_{2}$ & $\mathrm{n}_{3}$ & $\mathrm{n}_{4}$ & $\mathrm{n}_{5}$ & $\mathrm{n}_{6}$ & $\mathrm{n}_{7}$ & $\mathrm{n}_{8}$ & $\mathrm{n}_{9}$ & $\mathrm{n}_{10}$ & $\mathrm{n}_{11}$ \\
\hline$V_{A}^{a} \pm S D^{c}$ & $0.2 \pm 0.1$ & $1.4 \pm 0.1$ & $1.3 \pm 0.2$ & $1.2 \pm 0.0$ & $0.4 \pm 0.0$ & $0.7 \pm 0.1$ & $0.8 \pm 0.2$ & $1.3 \pm 0.1$ & $1.9 \pm 0.1$ & $0.8 \pm 0.1$ & $1.1 \pm 0.1$ \\
\hline$V_{p}^{b} \pm S D^{c}$ & $7.5 \pm 1.6$ & $28.6 \pm 0.2$ & $14.6 \pm 0.3$ & $8.2 \pm 0.4$ & $12.8 \pm 2.1$ & $14.8 \pm 1.5$ & $157.7 \pm 6.1$ & $25.4 \pm 3.4$ & $18.4 \pm 1.9$ & $87.8 \pm 0.0$ & $30.4 \pm 1.5$ \\
\hline
\end{tabular}

a: Acid value, ${ }^{\text {b: }}$ Peroxide value, ${ }^{c}$ SD: Standard deviation, $n=3$

Table 3. Fatty acid composition of safflower oil (type I) according to European Pharmacopeia monograph $7.0^{14}$

\begin{tabular}{ll} 
FAMEs & $\%(w / w)$ \\
\hline C16:0 & $4-10$ \\
\hline C18:0 & $1-5$ \\
\hline$\sum$ saturated FAMEs (C16:0 and C18:0) & $5-15$ \\
\hline C18:1 & $8-21$ \\
\hline C18:2 & $68-83$ \\
\hline Lunsaturated FAMEs (C18:1 and C18:2) & $76-105$ \\
\hline
\end{tabular}

Table 4. Fatty acid compositions of the oil samples by using GC-MS

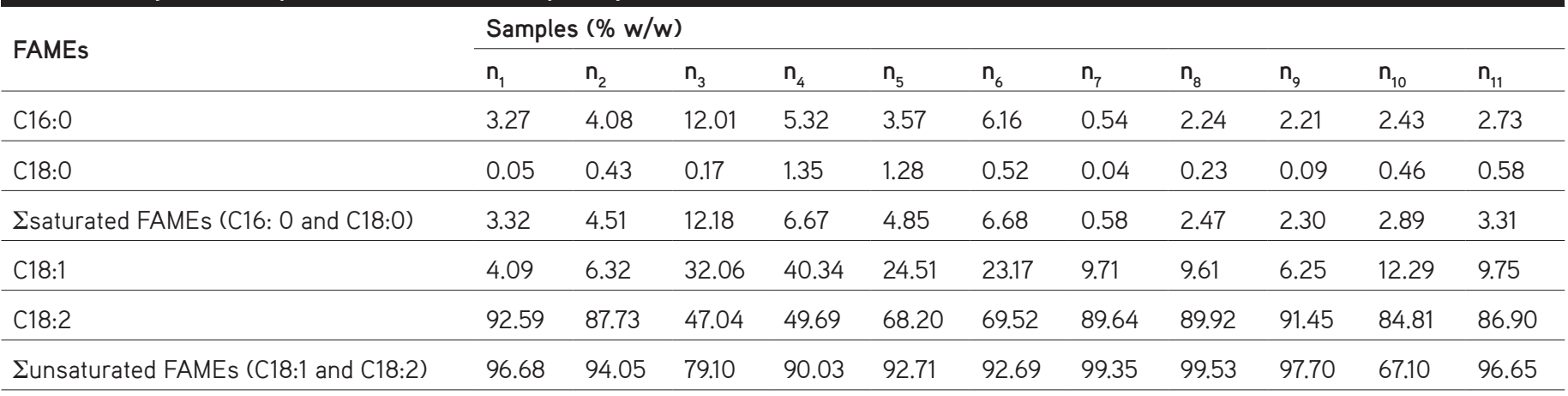


$\alpha$-Amylase and $\alpha$-glucosidase enzyme inhibitory activities of the oil samples

All oil samples were tested at concentrations of $0.25,0.5$, and $1.0 \mathrm{mg} / \mathrm{mL}$ to evaluate the inhibitory effects on both enzymes (Table 5). The results showed that safflower oil samples had no activity on $\alpha$-glucosidase, which is an enzyme that digest carbohydrates. A feeble $\alpha$-glucosidase inhibitory effect was detected only in sample number 11. The inhibition values of this sample were calculated as $6.70 \pm 2.55 \%$ at a concentration of $0.25 \mathrm{mg} / \mathrm{mL}$ and $4.58 \pm 1.03 \%$ at a concentration of $1 \mathrm{mg} /$ $\mathrm{mL}$. Inhibition values of acarbose used as the reference was determined as $98.19 \pm 0.53 \%(0.25 \mathrm{mg} / \mathrm{mL}), 99.53 \pm 0.04 \%(0.5$ $\mathrm{mg} / \mathrm{mL})$, and $99.57 \pm 0.04 \%(1 \mathrm{mg} / \mathrm{mL})$.

Generally, it was found that the oil samples did not show a significant inhibitory effect on $\alpha$-amylase. Only sample number 1 showed a moderate inhibitory activity $(52.13 \pm 2.87 \%)$ at a concentration of $1 \mathrm{mg} / \mathrm{ml}$. At the same concentration, acarbose displayed $100 \%$ inhibitory activity.

\section{DISCUSSION}

Acid value is used as a shelf-life monitoring parameter in the quality control of oils. The high free fatty acidity is one of the rancidity indicators of any oil and an increase in the oxidation potential of the oil and decreases stability. Except for oil samples 1 and 5, all samples were found to be rancid and oxidized. Peroxide value is a measure of the amount of active oxygen in oils, and the amount of peroxide in $1 \mathrm{~kg}$ oil in milliequivalent grams of oxygen. Oxygen causes smaller molecule fatty acids. Oils can deteriorate due to various factors (storage conditions, metal ions, temperature, light, etc.). The peroxide value shows oxidation state of the oil. It also indicates whether the deodorization process has been done effectively. ${ }^{17,18}$ Again, it was determined that all samples were highly oxidized except for oil samples 1 and 4 .
Palmitic, stearic, oleic, and linoleic acids were detected in all oil samples. It was determined that oleic acid (8.0-21.0\%) and linoleic acid (68.0-83.0\%), which were reported as the main fatty acids in the European Pharmacopoeia 7.0, were not among the desired amounts in the samples. The contradictory situation we detected in the samples for these two fatty acids led us to predict that oleic acid is oxidized into linoleic acid.

There are many in vitro and in vivo methods to evaluate the effects of pure compounds or plant extracts on weight control. In this study, the effects of safflower oils, which have been in high demand from pharmacies for weight control recently, on $\alpha$-amylase and $\alpha$-glucosidase that help carbohydrate digestion were evaluated and the oil samples did not show any inhibitory effect. However, the fact that none of the oil samples met the quality standards may have caused unpredictable interactions in activities of the enzymes.

Previously, Takahashi and Miyazawa ${ }^{19}$ studied the effects of $\mathrm{MeOH}$ extracts of safflower seeds on $\alpha$-glucosidase enzyme. As a result, compounds with stronger inhibitory effects than acarbose ( $N$ - $p$-coumaroyl serotonin and $N$-feruloyl serotonin) were isolated from the extract. ${ }^{19}$ However, it is clear that the secondary metabolite contents of seed oils will be different from seed $\mathrm{MeOH}$ extracts. In a study examining the activities of 10 fatty acids on enzymes known to be associated with diabetes, Su et al. ${ }^{20}$ showed that oleic and linoleic acids have potent glucosidase enzyme inhibitory activity. In short, the fact that the oils analyzed in this study were highly oxidized and the fatty acid content was not between the desired values should be a factor to be considered in determining the effectiveness. ${ }^{20}$

Safflower oils are among the commonly used oils because they have many activities (antioxidant, antiulcer, cardioprotective, antinociceptive, anti-inflammatory, hepatoprotective, anti-

\section{Table 5. $\alpha$-Amylase inhibition results of the oil samples}

\begin{tabular}{|c|c|c|c|}
\hline \multirow{2}{*}{ Samples } & \multicolumn{3}{|c|}{ Inhibition $\% \pm$ SD } \\
\hline & $0.25 \mathrm{mg} / \mathrm{mL}$ & $0.5 \mathrm{mg} / \mathrm{mL}$ & $1 \mathrm{mg} / \mathrm{mL}$ \\
\hline $\mathrm{n}_{1}$ & - & $5.37 \pm 2.87$ & $52.13 \pm 2.87$ \\
\hline $\mathrm{n}_{2}$ & $13.81 \pm 3.57$ & - & $7.73 \pm 0.86$ \\
\hline $\mathrm{n}_{3}$ & - & $15.53 \pm 3.26$ & $6.32 \pm 1.89$ \\
\hline $\mathrm{n}_{4}$ & $13.96 \pm 3.50$ & $3.42 \pm 1.05$ & $13.81 \pm 1.06$ \\
\hline $\mathrm{n}_{5}$ & $8.59 \pm 3.50$ & $4.91 \pm 1.77$ & - \\
\hline $\mathrm{n}_{6}$ & - & $11.52 \pm 1.07$ & - \\
\hline $\mathrm{n}_{7}$ & $8.11 \pm 2.86$ & $5.38 \pm 1.18$ & $21.08 \pm 7.68$ \\
\hline $\mathrm{n}_{8}$ & $16.09 \pm 3.73$ & $17.23 \pm 1.05$ & $24.45 \pm 5.06$ \\
\hline $\mathrm{n}_{9}$ & $28.37 \pm 4.90$ & $20.93 \pm 2.40$ & $24.66 \pm 2.81$ \\
\hline $\mathrm{n}_{10}$ & $40.38 \pm 3.25$ & $18.15 \pm 4.14$ & $16.98 \pm 2.98$ \\
\hline $\mathrm{n}_{11}$ & - & $7.54 \pm 1.83$ & $4.01 \pm 5.50$ \\
\hline Acarbose & $92.70 \pm 5.80$ & $98.45 \pm 6.66$ & $100.00 \pm 0.04$ \\
\hline
\end{tabular}

-: No inhibition, SD: Standard deviation, $\mathrm{n}=3$ 
cancer, antidiabetic, and weight control activities ${ }^{21-26}$ as well as their use in food and cosmetics, while most of these health benefits are associated with the oil content and the fatty acid composition of the respected oils. These oils, which contain significant number of oxygen radicals, will cause serious health problems after chronic exposure, especially considering that they are used daily by people who buy them for weight control. Meanwhile, evaluating the effectiveness of safflower oils on weight control with other methods can be considered another research topic. In conclusion, the high oxidation rates and significant variability in fatty acid content (especially for unsaturated fatty acids) detected in 11 purchased samples indicated that more attention should be paid to the quality control of these oils, which points out to fact that they would be beneficial in terms of the health benefits expected from safflower oils.

\section{CONCLUSION}

Our literature survey has shown that quality control analysis of the safflower oils in Turkish market and their effectiveness on two enzymes ( $\alpha$-amylase and $\alpha$-glucosidase) was performed in this study for the first time. Within this study, we conducted in 11 safflower oil samples we bought from the market; it was concluded that these oil samples did not meet the quality criteria required by European Pharmacopoeia for safflower oil. Interestingly, it was observed that the amount of oleic acid was very low, while the amount of linoleic acid was high. This result suggested that oleic acid in oils was oxidized to linoleic acid due to the production methods and storage conditions. The results of enzyme inhibitory activities of the safflower oil samples showed that these oils could not have any effect on weight control by inhibiting the enzymes that provide carbohydrate digestion.

Safflower, whose market cap and production are low, may be the hope of closing the vegetable oil gap for the present/future of the growing world's population demand. In addition to increasing oil production, the end product also meets the expectations in terms of quality. Likewise, if the oil is used or at least marketed with health claims (with or without pharmaceutical usage), to establish the necessary quality criteria and show no harm to the user, the safflower oil (if for human use) needs to be encouraged to be European Pharmacopoeia compliance.

\section{Ethics}

Ethics Committee Approval: There is no requirement for ethical approval.

Informed Consent: Not applicable.

Peer-review: Externally peer-reviewed.

\section{Authorship Contributions}

Concept: D.D.O., Design: D.D.O., Data Collection or Processing: D.D.O., D.S., S.P., B.Ö., A.B., O.K.U., Analysis or Interpretation: D.D.O., D.S., S.P., B.Ö., A.B., O.K.U., Literature Search: D.D.O., O.K.U., Writing: D.D.O., O.K.U.

Conflict of Interest: No conflict of interest was declared by the authors.
Financial Disclosure: The authors declared that this study received no financial support.

\section{REFERENCES}

1. Kıllı F, Beycioğlu T. Oil seeds and crude oil production in the World and Turkey, problems of oilseeds production in Turkey. IJAAES. 2019;1:17-33.

2. Zhou X, Tang L, Xu Y, Zhou G, Wang Z. Towards a better understanding of medicinal uses of Carthamus tinctorius $L$. in traditional Chinese medicine: a phytochemical and pharmacological review. J Ethnopharmacol. 2014;151:27-43.

3. Carthamus tinctorius taxon page, Turkish Plants Data Service, 2021.

4. Farmasötik Botanik Ders Kitabı. Baytop A. İstanbul, İstanbul Üniversitesi, 1996.

5. Classification for kingdom plantae down to species Carthamus tinctorius L., United States Department of Agriculture Natural Resources Conservation Service, 2021.

6. Mendes-da-Silva RF, Ferreira DJS, Lopes-de-Morais AAC, de Macêdo PFC, Lagranha CJ, Batista-de-Oliveira-Hornsby M. Safflower (Carthamus tinctorius L.) oil during pregnancy and lactation influences brain excitability and cortex oxidative status in the rat offspring. Nutr Neurosci. 2018;21:753-760.

7. Gautam S, Bhagyawant SS, Srivastava N. Detailed study on therapeutic properties, uses and pharmacological applications of safflower (Carthamus tinctorius L.). Int J Ayur Pharma Res. 2014:2:1-4.

8. Crampon C, Nikitine C, Zaier M, Lepine O, Tanzi CD, Vian MA, Chemat F, Badens E. Oil extraction from enriched Spirulina platensis microalgae using supercritical carbon dioxide. J Supercritic Fluids. 2017;119:289-296.

9. Scientific opinion on the substantiation of health claims related to Carthamus tinctorius L. and maintenance of skin (id 2748) and maintenance of hair (id 4242) pursuant to article 13(1) of regulation (ec) no 1924/2006, Authority EFS, 2009.

10. Wang $\mathrm{Y}$, Chen P, Tang C, Wang Y, Li Y, Zhang H. Antinociceptive and anti-inflammatory activities of extract and two isolated flavonoids of Carthamus tinctorius L. J Ethnopharmacol. 2014;151:944-950.

11. Konopka I, Roszkowska B, Czaplicki S, Tańska M. Optimization of pumpkin oil recovery by using aqueous enzymatic extraction and comparison of the quality of the obtained oil with the quality of cold-pressed oil. Food Technol Biotechnol. 2016;54:413-420.

12. Emongor V. Safflower (Carthamus tinctorius L.) the underutilized and neglected crop: a review. Asian J Plant Sci. 2010;9:299-306.

13. Composition of fatty acids by gas chromatography. Commission EP. $8^{\text {th }}$ ed. Strasbourg, France, European Pharmacopeia 8.0. 2013;136-137.

14. EU. European pharmacopeia $7^{\text {th }}$ edition. In: Healthcare EDftQoMa (ed). Vol 1. Germany, Druckerei C.H. Beck Press, 2011;1346.

15. EU. European pharmacopeia $8^{\text {th }}$ edition. In: Healthcare EDftQoMa (ed). Vol a. Germany, Druckerei C.H. Beck Press, 2014;155.

16. Nutritional labeling fames on rt-2560 by AOAC method 996.06: https:// ez.restek.com/images/cgram/gc_ff1346.pdf

17. Ali H, Houghton PJ, Soumyanath A. Alpha-amylase inhibitory activity of some Malaysian plants used to treat diabetes; with particular reference to Phyllanthus amarus. J Ethnopharmacol. 2006;107:449-455.

18. Lam SH, Chen JM, Kang CJ, Chen CH, Lee SS. Alpha-glucosidase inhibitors from the seeds of Syagrus romanzoffiana. Phytochemistry. 2008;69:1173-1178. 
19. Takahashi T, Miyazawa M. Potent $\alpha$-glucosidase inhibitors from safflower (Carthamus tinctorius L.) seed. Phytother Res. 2012;26:722-726.

20. Su CH, Hsu CH, Ng LT. Inhibitory potential of fatty acids on key enzymes related to type 2 diabetes. Biofactors. 2013;39:415-421.

21. Khalid N, Khan RS, Hussain MI, Farooq M, Ahmad A, Ahmed I. A comprehensive characterisation of safflower oil for its potential applications as a bioactive food ingredient - a review. Trends Food Sci Technol. 2017;66:176-186.

22. Han J, Cheng L, Zhang R, Bi J. Extraction of safflower seed oil by supercritical $\mathrm{CO}_{2}$. J Food Eng. 2009;92:370-376.
23. Davis PH. Flora of Turkey and The East Aegeans Islands (vol. 5). Edinburgh England; The University Press; 1975.

24. Rashmi Dehariya AKD. A review on potential pharmacological uses of Carthamus tinctorius L. World J Pharm Sci. 2015;3:1741-1747.

25. Safflower. Smith JR. Taylor \& Francis, 1996.

26. Arslan Y, Katar D, Güneylioğlu H, Subaşı I, Şahin B, Bülbül AS. Arslan Y, Katar D, Güneylioğlu H, Subașı İ, Şahin B, Bülbül AS. The wild species of Carthamus L. in natural flora of Turkey and possibilities of using safflower breeding. J Central Res Inst Field Crops. 2010;19:36-43. 